\title{
GROWTH AND DIET OF INTRODUCED COREGONID FISH COREGONUS PELED (GMELIN) AND COREGONUS LAVARETUS (L.) IN TWO BELGIAN RESERVOIR LAKES
}

\author{
C. MAlbroucK ${ }^{1},-$ P. MerGeN ${ }^{2} *-$ J.-C. MichA ${ }^{1}$ \\ *e-mail: Patricia.Mergen@africamuseum.be \\ ${ }^{1}$ Research Unit in Organismic Biology, Facultés Universitaires Notre-Dame de la Paix \\ 61, rue de Bruxelles -5000 Namur, Belgium \\ (phone: +32-81-724364; fax: +32-81-724420) \\ ${ }^{2}$ Royal Museum for Central Africa, Department of Zoology \\ Leuvensesteenweg 13, 3080 Tervuren, Belgium \\ (phone: +32-2-769-5624; fax: +32-2-769-5642) \\ *Corresponding author
}

(Received 22 $2^{\text {th }}$ June 2005; accepted $4^{\text {th }}$ August 2005)

\begin{abstract}
Introduced Coregonus lavaretus L. and Coregonus peled Gmelin populations in the Robertville and Bütgenbach Reservoir lakes (Belgium) were studied in order to assess their adaptation to their new habitat. We considered the evolution of abundance, biomass, size distribution structure, growth parameters and diet. Maximal temperature values are acceptable for $C$. peled but slightly too high for an optimal development of $C$. lavaretus. In order to remain in their acceptable range for dissolved oxygen, the coregonids must stay in surface water during stratification, although water temperature is largely above their optimum in these water layers. Length frequency diagrams established for C. peled in both lakes show only older cohorts, which indicate that there is no natural reproduction. Slope coefficients for $C$. peled in both lakes indicate an allometric growth $(b<3)$, length increasing proportionally more rapidly than weight. $C$. lavaretus shows a broad diet spectrum with 14 categories whereas $C$. peled seems to have a more narrow diet spectrum. In our case $C$. peled shows an essentially zooplankton oriented diet in both lakes. In conclusion, the Bütgenbach and Robertville reservoir lakes seem to meet the habitat requirements of $C$. lavaretus and $C$. peled in terms of growth capacities and diet composition. On the other hand, the conditions necessary for the natural reproduction of these two species do not seem to be totally fulfilled, probably due to the trophic status and the fluctuations of the water level as consequence of reservoir operations.
\end{abstract}

Keywords: abundance, biomass, size distribution structure, growth parameters, diet.

\section{Introduction}

The genus Coregonus belongs to the class Actinopterygii, order Salmoniforms, family of Salmonidae and subfamily of Coregoninae [47]. The two species considered in this study are Coregonus lavaretus (L.) and Coregonus peled (Gmelin). C. lavaretus has a small low mouth with protruding upper jaw and a quite slender silvery body [27]. Maximum length reaches up to $130 \mathrm{~cm}$ with a mean value of 50 to $70 \mathrm{~cm}$. Maximum mass is up to $10 \mathrm{~kg}$ for a mean value of 2 to $4 \mathrm{~kg}$. Compared to C. lavaretus, C. peled has a broader body and a terminal mouth. Maximum length reaches $60 \mathrm{~cm}$ with a mean value of 30 to $40 \mathrm{~cm}$, while maximum mass reaches $5 \mathrm{~kg}$ with a mean value up to $1 \mathrm{~kg}$. According to [30] the natural distribution area of $C$. lavaretus in Europe covers the Baltic Sea, the North Sea and the Arctic Ocean up to the Kolyma River (Eastern Siberia). The species is still present in numerous lakes as a glacial relict (Poland, alpine lakes). This species has been stocked since 1880 [46] into many other places in Europe outside of its native range. The natural distribution of C. peled covers lakes and rivers of 
the Arctic Ocean basin from the Mézen River (Russia) to the Kolyma River. Since 1954 [17] this species has been widely introduced in North and Central European lakes. These two species have been introduced in 1978 [13] in the reservoir lakes of Robertville and Bütgenbach (Belgium) from strains originating from Bohemia (currently Czech Republic). From 1979 to 1995 the introduced fish were adults with a mean length of $30 \mathrm{~cm}$. Only from $1991 \mathrm{on}$, the restocked species has been identified as mainly C. lavaretus. From 1996 on, restocking experiments with C. lavaretus larvae (2 $\mathrm{cm}$ ) were conducted (Table 1).

Table 1. Introduction of Coregonids in the Bütgenbach and Robertville reservoirs from 1978 to $1999(T L=$ total length in $\mathrm{cm}, T B=$ total biomass in $\mathrm{kg}, \mathrm{Ab} .=$ Abundance in number of individuals, IMW = individual mean weight in $g$ )

\begin{tabular}{|c|c|c|c|c|c|c|c|c|c|c|}
\hline & \multicolumn{5}{|c|}{ Bütgenbach } & \multicolumn{5}{|c|}{ Robertville } \\
\hline Date & TL (cm) & TB (kg) & Ab. (n) & I M W (g) & Species & TL (cm) & TB (kg) & Ab. (n) & I M W (g) & Species \\
\hline NOV - 78 & $5-6$ & & \begin{tabular}{|l|}
50000 \\
\end{tabular} & & uknown & $5-6$ & & 25000 & & uknown \\
\hline NOV - 79 & $12-30$ & 750 & & & uknown & $12-30$ & 1250 & & & uknown \\
\hline NOV - 80 & & & & & uknown & & & & & uknown \\
\hline NOV - 81 & & 675 & & & uknown & & 675 & & & uknown \\
\hline NOV - 82 & & 570 & & & uknown & & 570 & & & uknown \\
\hline NOV - 83 & & 437 & & & uknown & & 437 & & & uknown \\
\hline NOV - 84 & & 525 & & & uknown & & 525 & & & uknown \\
\hline NOV - 85 & & 500 & & & uknown & & 500 & & & uknown \\
\hline NOV - 86 & & 570 & & & uknown & & 570 & & & uknown \\
\hline NOV - 87 & & 850 & & & uknown & & 850 & & & uknown \\
\hline NOV - 88 & & 750 & & & uknown & & 750 & & & uknown \\
\hline NOV - 89 & $19-29$ & 750 & & 177 & uknown & $19-29$ & 750 & & 177 & uknown \\
\hline NOV - 90 & $26-30$ & 750 & & 220 & uknown & $26-30$ & 750 & & 220 & uknown \\
\hline$\overline{N O V-91}$ & $26-35$ & 750 & & 200 & $99,7 \%$ C. lavaretus & $26-35$ & 750 & & 200 & 99,7 \% C. lavaretus \\
\hline NOV - 92 & $18-30$ & 750 & & 144 & Mainly C. lavaretus & $18-30$ & 750 & & 144 & Mainly C. lavaretus \\
\hline NOV - 93 & $12-22$ & 600 & & 49 & Mainly C. lavaretus & $12-22$ & 900 & & 49 & Mainly C. lavaretus \\
\hline NOV - 94 & $21-33$ & 600 & & & $74 \%$ C. lavaretus & $21-33$ & 900 & & & $74 \%$ C. lavaretus \\
\hline OCT- 95 & $12-42$ & 600 & & & $99.7 \%$ C. lavaretus & $12-42$ & 900 & & & $99.7 \%$ C. lavaretus \\
\hline FEB - 96 & 2 & & 472000 & & C. lavaretus larva & 2 & & 1200000 & & C. lavaretus larva \\
\hline NOV - 97 & $3.1-3.9$ & & & & C. lavaretus & $3.1-3.9$ & & & & C. lavaretus \\
\hline NOV - 98 & $1.2-1.6$ & & & & C. lavaretus & $1.2-1.6$ & & & & C. lavaretus \\
\hline JAN - 99 & $2.8-4.0$ & & & & C. peled & $2.8-4.0$ & & & & C. peled \\
\hline
\end{tabular}

The aim of this study was to assess the adaptation of these two introduced species to their new environment. Different aspects were considered, starting with a survey of the evolution of abundance, biomass and size distribution structure of the coregonid populations from 1994 to 2000. Growth parameters were established for the 1996/1997 cohorts. Detailed dietary studies were conducted in 1996/1997 and in 1999/2000.

\section{Materials and Methods}

\section{Study Area}

Located in the eastern part of the province of Liège (Belgium), the man-made lakes of Robertville $\left(50^{\circ} 27^{\prime} \mathrm{N} ; 6^{\circ} 07^{\prime} \mathrm{E}\right)$ and Bütgenbach $\left(50^{\circ} 25^{\prime} \mathrm{N} ; 6^{\circ} 14^{\prime} \mathrm{E}\right)$ were respectively constructed in 1929 and 1932 on the upper reaches of the Warche River (Fig. 1). The Bütgenbach Reservoir is located $7 \mathrm{~km}$ upstream from the Robertville Reservoir. Owned by the S.A. Electrabel, their main function is the production of hydroelectric power. The fishing activities are managed by the "Ligue Royale de Propagande des Pêcheurs de l'Est". 


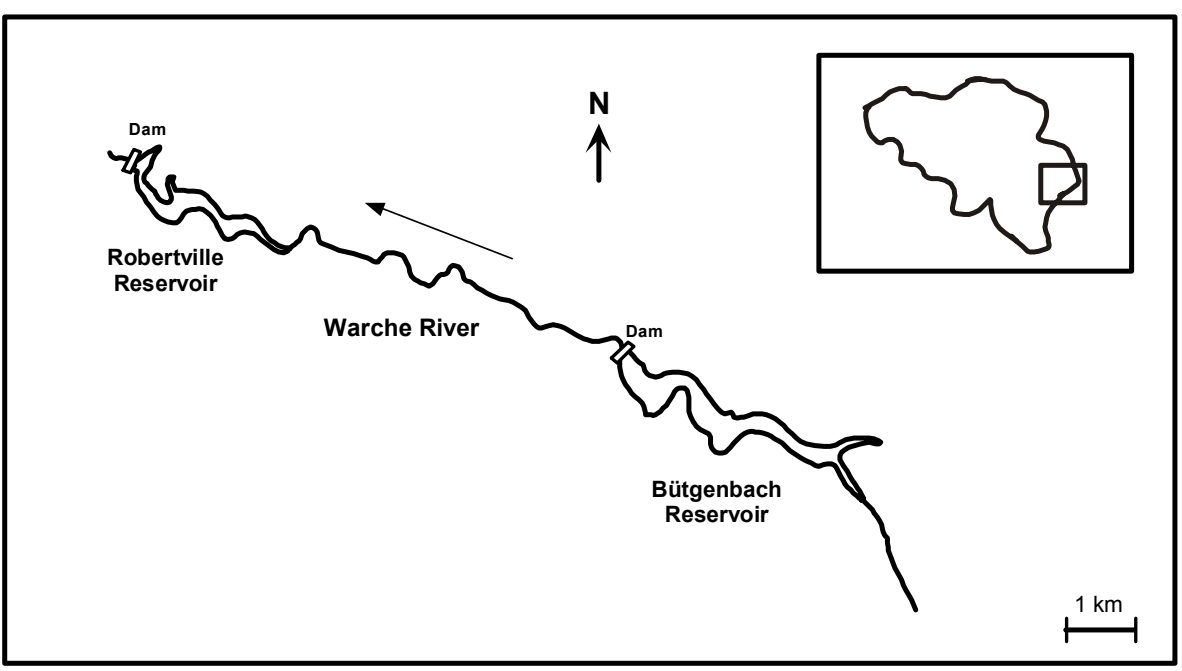

Figure 1. Map of the study area: The Reservoir Lakes of Robertville and Bütgenbach (Belgium)

Both reservoirs are known to display a tendency to eutrophication [26, 25]). The morphometric and hydrologic data concerning both lakes can be found in Table 2.

Table 2. Morphometric and hydrological features of Bütgenbach and Robertville reservoirs [25]

\begin{tabular}{|l|c|c|}
\hline Features & Bütgenbach & Robertville \\
\hline Altitude $(\mathrm{m})$ & 550 & 490 \\
\hline Length $(\mathrm{km})$ & 3,4 & 3,5 \\
\hline Mean width (m) & 280 & 150 \\
\hline Mean surface area (ha) & 120 & 63 \\
\hline Volume $\left(10^{6} \mathrm{~m}^{3}\right)$ & 23 & 7,7 \\
\hline Maximum depth (m) & 11 & 47 \\
\hline Mean depth (m) & 9,6 & 12,2 \\
\hline Mean yearly depth fluctuation (m) & 6 & 3 \\
\hline
\end{tabular}

\section{Sampling methods}

Physicochemical variables $(\mathrm{pH}$, temperature, dissolved oxygen and conductivity at $20^{\circ} \mathrm{C}$ ) were directly measured in the field, on water samples collected with a Van Doorn bottle (in 1996) from April to November up to $20 \mathrm{~m}$ depth in Bütgenbach, and 40 $\mathrm{m}$ in Robertville. Samples of $500 \mathrm{ml}$ were collected for nutrients $\left(\mathrm{PO}_{4}{ }^{-}, \mathrm{P}_{\text {total }}, \mathrm{NH}_{4}{ }^{+}\right.$, $\mathrm{NO}_{2}^{-}, \mathrm{NO}_{3}^{-}$) and Chlorophylle $\boldsymbol{a}$ analysis. During the 1999/2000 campaign, the physicochemical parameters were measured with a Hydrolab multiparameter probe every $2,5 \mathrm{~m}$ up to $10 \mathrm{~m}$ in Robertville and up to $15 \mathrm{~m}$ in Bütgenbach. During the $1999 / 2000$ campaign, water samples were collected on a weekly basis from July to November 1999 and from March to July 2000 for phytoplankton and zooplankton analysis. Phytoplankton was filtered on Whatman GF/C $0,22 \mu \mathrm{m}$ filters from a volume of $500 \mathrm{ml}$ water collected using a Van Doorn bottle at the same depths as mentioned before. These extracts were analysed for pigment composition by HPLC in the lab. The zooplankton was sampled at the same depth with a 101 Schindler trap equipped with a $65 \mu \mathrm{m}$ filter. Samples were fixed with a $4 \%$ formaldehyde solution for microscopical 
identification. Fish were sampled from spring to autumn, between 1994 and 2000 by, surface and bottom horizontal gill netting in both lakes. One gill net set is composed of 8 nets with mesh sizes ranging from 10 to $80 \mathrm{~mm}$ with a step of $10 \mathrm{~mm}$. Each panel has a length of $50 \mathrm{~m}$ for a height of $1.5 \mathrm{~m}$. The panels are attached together to form a set of $400 \mathrm{~m}$ for a surface of $600 \mathrm{~m}^{2}$ (Fig.2).

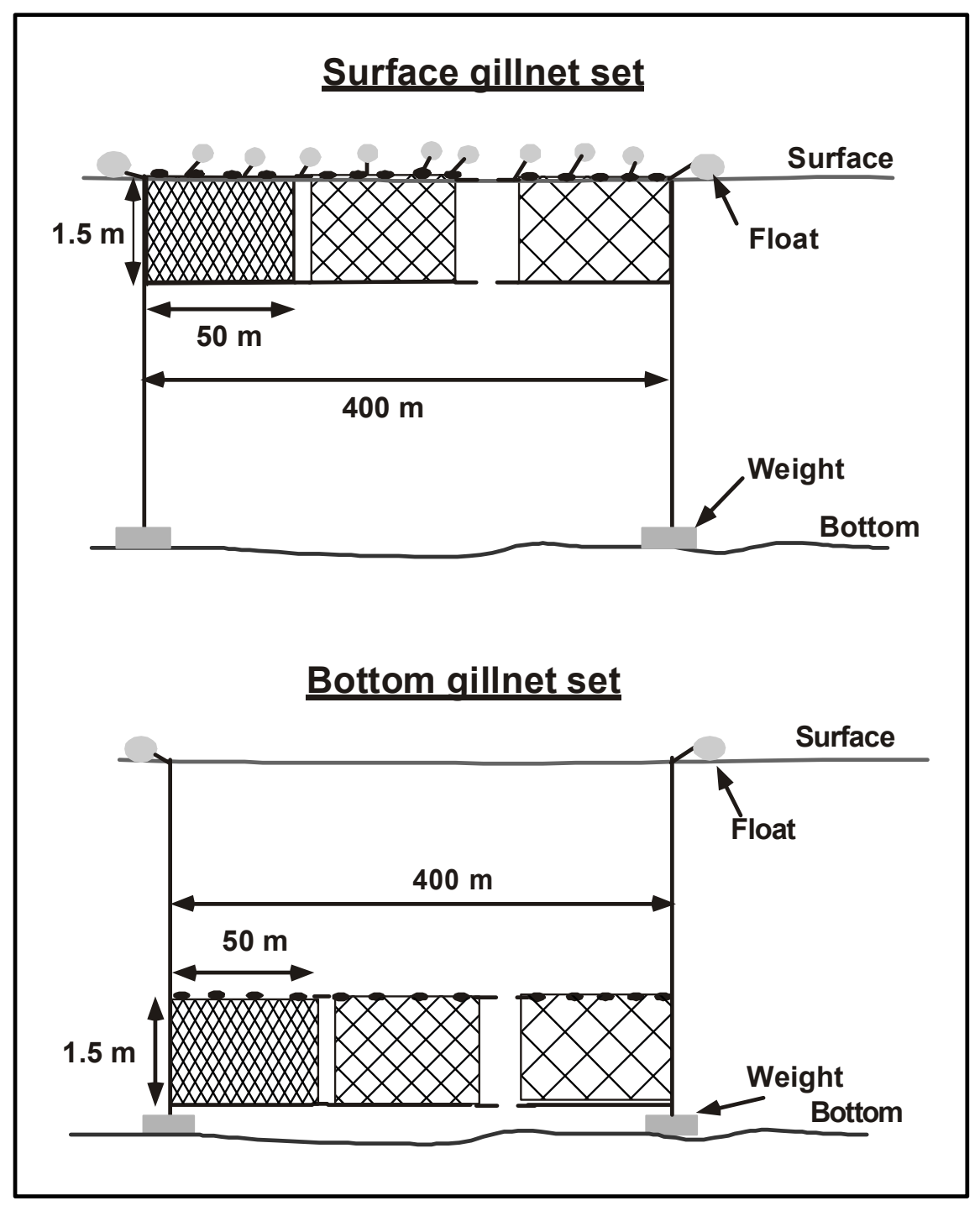

Figure 2. Horizontal gill netting device used for fish sampling [24]

Fish were weighted to the nearest $1 \mathrm{~g}$, total length $\left(\mathrm{L}_{\mathrm{T}}\right)$ was measured to the nearest 1 $\mathrm{mm}$. Scales for age determination and growth parameter calculations were pulled from the upper flank region above the lateral line, behind the dorsal fin. In 1996/1997 and in 1999/2000, stomach contents were also removed for diet analysis. For zooplankton identification the determination keys of $[16,1,33]$ were used.

\section{Data Analysis}

Length-weight relationships [21] were studied

$$
W_{t}=a^{*} L_{t}^{b}
$$


where $\mathrm{W}_{\mathrm{t}}=$ total weight in $\mathrm{g}, \mathrm{L}_{\mathrm{t}}=$ total length in $\mathrm{mm}, \mathrm{a}, \mathrm{b}=$ constants.

Constant $b$ allows us to establish the allometric condition factor [34],

$$
C=\frac{L_{t}}{W_{t}^{b}} * 10^{5}
$$

Growth performances between the two lakes were compared by homogeneity slope tests [10] after linear transformation of the length-weight relationship:

$$
\log W_{t}=\log a+b^{*} \log L_{t} .
$$

The growth model of [5] was used on the 1996/1997 cohort data

$$
L_{t}=L_{\infty} *\left[1-e^{-k^{*}\left(t-t_{0}\right)}\right\rfloor
$$

where $\mathrm{L}_{\mathrm{t}}=$ total length in $\mathrm{mm}, \mathrm{L}_{\infty}=$ the maximum theoretical length in $\mathrm{mm}, \mathrm{K}=$ Growth coefficient indicating the rate by which the length tend to $\mathrm{L}_{\infty}, \mathrm{t}_{0}$ is the theoretical age of the fish at length 0 .

Stomach contents were analysed in four ways. First by Occurrence Index [19],

$$
I_{0}=\frac{N_{a}}{N_{t}} * 100
$$

where $\mathrm{N}_{\mathrm{a}}=$ number of stomachs where the item is present, $\mathrm{N}_{\mathrm{t}}=$ total number of nonempty stomachs. Secondly by Abundance Index [19]

$$
I_{a}=\frac{N_{x}}{N_{x t}} * 100
$$

where $\mathrm{Nx}=$ number of individuals belonging to the food category $\mathrm{x}, \mathrm{N}_{\mathrm{xt}}=$ total number of individuals in the different food categories $x$. Thirdly by Biomass Index

$$
I_{b}=\frac{B_{x}}{B_{x t}} * 100
$$

where $\mathrm{B}_{\mathrm{x}}=$ biomass in $\mu \mathrm{g}$ of the individuals belonging to the food category $\mathrm{x}$ and $\mathrm{B}_{\mathrm{xt}}=$ total biomass of the individuals in the different food categories x. Dry weight conversion equations were used for the phytoplankton [39] and the zooplankton [42].

Fourthly by Selectivity Index [9]

$$
\alpha=\frac{\frac{r_{a}}{p_{a}}}{\sum_{i=1}^{n} \frac{r_{i}}{p_{i}}}
$$

where $\mathrm{n}=$ number of prey categories in the sample, $\mathrm{r}_{\mathrm{a}}=$ abundance of the prey category $\mathrm{a}$ in the stomach content, $\mathrm{p}_{\mathrm{a}}=$ abundance of prey category a in the field $\left(\mathrm{m}^{3}\right), \mathrm{r}_{\mathrm{i}}=$ abundance of the $i^{\text {st }}$ prey category in the stomach content, $p_{i}=$ abundance of the $i^{\text {st }}$ prey category in the field $\left(\mathrm{m}^{3}\right)$. 


\section{Results}

\section{Physicochemical features}

The minimum and maximal values of the physicochemical parameters measured during the 1996 campaign from April to November are shown in Table 3. The thermal stratification period in Bütgenbach extends from April to September with a maximal surface value of $20.4{ }^{\circ} \mathrm{C}$ in August. The hypolimnion is anoxic from June to September. In August anoxic conditions are already visibled at $7 \mathrm{~m}$ depth near the dam and Chlorophyl $\boldsymbol{a}$ values rise up to $140 \mu \mathrm{g} / \mathrm{l}$ in the first two meters from the surface. In Robertville, the thermal stratification period extends from May to September with a maximal value of $19.5^{\circ} \mathrm{C}$ in August.

Table 3. Physico-chemical features of the Bütgenbach and Robertville Reservoirs during the 1996 sampling campaigns from April to November (in bold mean values, in standard respectively minimum and maximum values)

\begin{tabular}{|c|c|c|}
\hline & Bütgenbach & Robertville \\
\hline Temperature $\left({ }^{\circ} \mathrm{C}\right)$ & $1.9-12.8-20.4$ & $2.2-10.4-19.5$ \\
\hline Transparency (m) & $0.8-1.7-1.9$ & $0.7-2.6-4.6$ \\
\hline Conductivity $(\mu \mathrm{S} / \mathrm{cm})$ & $102-129-204$ & $109-129-158$ \\
\hline Dissolved Oxygen (mg/l) & $0-10.7-14.6$ & $0-6.7-19.4$ \\
\hline Chlorophylle a $(\mu \mathrm{g} / \mathrm{l})$ & $5.1-35.9-140$ & $1.4-13.4-45.5$ \\
\hline $\mathrm{PO}_{4}^{-}(\mu \mathrm{g} / \mathrm{l})$ & $<5-[?]-48$ & $<5-[?]-41$ \\
\hline $\mathrm{NH}_{4}^{-}(\mu \mathrm{g} / \mathrm{l})$ & $<3-[?]-909$ & $<3-[?]-259$ \\
\hline $\mathrm{NO}_{2}^{-}(\mu \mathrm{g} /)$ & $1-22-60$ & $4-30-72$ \\
\hline $\mathrm{NO}_{3}^{-}(\mu \mathrm{g} / \mathrm{l})$ & $1280-2160-4015$ & $680-2496-4970$ \\
\hline$N(\mu g / l)$ & $1323-2346-3590$ & $788-2455-5700$ \\
\hline
\end{tabular}

The hypolimnion is anoxic from late May until mid-October. Anoxic conditions are also encountered at less than $10 \mathrm{~m}$ depth near the dam in August. Chlorophyl $\boldsymbol{a}$ values are lower than in Bütgenbach, with a maximum value of $45.5 \mu \mathrm{g} / 1$ in August.

The physicochemical parameters measured during the 1999-2000 campaign are shown in Table 4.

Table 4. Physico-chemical features of the Bütgenbach and Robertville Reservoirs during the 1999/2000 sampling campaigns (from July 99 to October 99 and from March 00 - June 00).

\begin{tabular}{|l|r|r|r|r|r|r|r|r|}
\hline & \multicolumn{4}{|c|}{ Bütgenbach } & \multicolumn{3}{c|}{ Robertville } \\
\cline { 2 - 9 } & \multicolumn{2}{|c|}{1999} & \multicolumn{2}{|c|}{2000} & \multicolumn{2}{c|}{1999} & \multicolumn{2}{c|}{2000} \\
\cline { 2 - 9 } & Min value & Max value & Min value & Max value & Min value & Max value & Min value & Max value \\
\hline Temperature $\left({ }^{\circ} \mathrm{C}\right)$ & 7 & 22 & 5 & 22 & 12 & 22 & 6 & 22 \\
\hline Conductivity $(\mu \mathrm{S} / \mathrm{cm})$ & 105 & 125 & 95 & 105 & 114 & 129 & 101 & 117 \\
\hline Dissolved Oxygen $(\mathrm{mg} / \mathrm{l})$ & 0 & 14 & 0 & 12 & 0 & 13 & 0 & 13 \\
\hline Dissolved Oxygen $(\%)$ & 0 & 150 & 0 & 120 & 0 & 141 & 0 & 137 \\
\hline pH & 6.2 & 9.2 & 5.7 & 9.8 & 6.4 & 9 & 6.9 & 9.4 \\
\hline
\end{tabular}

Temperatures in surface waters are higher than $20^{\circ} \mathrm{C}$ during summer in both lakes. A thermal stratification is also observed in both lakes from July to September. Mixing 
takes place in October. Dissolved oxygen concentrations drop below $4 \mathrm{mg} / \mathrm{l}$ at a depth of $7 \mathrm{~m}$ in the Bütgenbach reservoir during summer. Anoxic conditions are the rule under $8 \mathrm{~m}$ depth. These phenomena are observed in Robertville as well, but at a depth of 10 $\mathrm{m}$.

\section{Abundance and Biomass}

In terms of abundance and biomass $C$. peled largely dominates $C$. lavaretus in both lakes although restocking mainly concerns the later species (Table 5).

Absolute and relative contributions of both species are higher in Robertville than in Bütgenbach. From 1999 on, there were no more captures of $C$. lavaretus.

Table 5. Coregonus lavaretus and Coregonus peled gillnetting results for the Bütgenbach and Robertville Reservoirs from June 1994 to August 1999 (Ab. (n) = Abundance in number of captured individuals, Rel. Ab. (\%) = Relative abundance with regards to the total abundance of all fish species captured, Biom (kg) = Biomass in $\mathrm{kg}$, Biom. Rel (\%) = Relative biomass).

\begin{tabular}{|c|c|c|c|c|c|c|c|c|}
\hline & \multicolumn{8}{|c|}{ BÜTGENBACH } \\
\hline & \multicolumn{4}{|c|}{ C. lavaretus } & \multicolumn{4}{|c|}{ C. peled } \\
\hline & $\mathrm{Ab} .(\mathrm{n})$ & Rel. Ab. (\%) & Biom (kg) & Rel. Biom. (\%) & Ab. (n) & Rel. Ab. (\%) & Biom (kg) & Rel. Biom. (\%) \\
\hline June 1994 & 13 & 1,59 & \begin{tabular}{r|}
1 \\
\end{tabular} & 0,50 & 248 & 30,28 & 139 & 69,85 \\
\hline October 1994 & 0 & 0,00 & 0 & 0,00 & 85 & 7,21 & 62 & 46,97 \\
\hline May 1995 & 4 & 0,60 & 1 & 0,91 & 83 & 12,48 & 54 & 49,09 \\
\hline September 1995 & 2 & 0,25 & 0 & 0,00 & 32 & 4,06 & 22 & 25,58 \\
\hline October 1995 & 4 & 0,58 & 1 & 0,62 & 151 & 21,82 & 110 & 68,32 \\
\hline June 1996 & 14 & 1,25 & 5 & 2,81 & 125 & 11,12 & 98 & 55,06 \\
\hline September 1996 & 0 & 0,00 & 0 & 0,00 & 66 & 18,80 & 59 & 64,13 \\
\hline September 1997 & 2 & 0,21 & 3 & 1,66 & 83 & 8,60 & 69 & 44,14 \\
\hline October 1998 & 0 & 0,00 & 0 & 0,00 & 31 & 8,49 & 33 & 40,53 \\
\hline August 1999 & 0 & 0,00 & 0 & 0,00 & 4 & 0,59 & 3 & 14,35 \\
\hline \multirow[t]{4}{*}{ Total } & 39 & 0,5 & 11 & 0,9 & 908 & 11,9 & 648 & 53,2 \\
\hline & \multicolumn{8}{|c|}{ ROBERTVILLE } \\
\hline & \multicolumn{4}{|c|}{ C. lavaretus } & \multicolumn{4}{|c|}{ C. peled } \\
\hline & Ab. (n) & Rel. Ab. (\%) & Biom (kg) & Rel. Biom. (\%) & Ab. (n) & Rel. Ab. (\%) & Biom (kg) & Rel. Biom. (\%) \\
\hline June 1994 & 1 & 0,07 & \begin{tabular}{r|}
0 \\
\end{tabular} & 0,00 & 365 & 25,10 & 301 & 79,84 \\
\hline October 1994 & 7 & 1,19 & 2 & 2,33 & 47 & 7,97 & 42 & 48,84 \\
\hline May 1995 & 35 & 4,33 & 8 & 4,42 & 159 & 19,65 & 114 & 62,98 \\
\hline September 1995 & 0 & 0,00 & 0 & 0,00 & 66 & 11,54 & 54 & 52,94 \\
\hline October 1995 & 0 & 0,00 & 0 & 0,00 & 152 & 19,84 & 124 & 70,45 \\
\hline June 1996 & 24 & 4,69 & 9 & 7,83 & 77 & 15,04 & 69 & 60,00 \\
\hline September 1996 & 5 & 1,65 & 1 & 0,93 & 72 & 23,76 & 78 & 72,90 \\
\hline September 1997 & 16 & 2,35 & 7 & 5,19 & 70 & 10,28 & 74 & 54,81 \\
\hline October 1998 & 2 & 0,65 & 1 & 1,39 & 22 & 7,10 & 27 & 52,22 \\
\hline August 1999 & 0 & 0,00 & 0 & 0,00 & 7 & 3,20 & 7 & 15,46 \\
\hline Total & 90 & 1,4 & 28 & 2,0 & 1037 & 16,7 & 890 & 64,6 \\
\hline
\end{tabular}

\section{Growth}

Length frequency diagrams have been established for C. peled (Fig. 3), but not for $C$. lavaretus because of its low abundance in both reservoirs. C. lavaretus total length ranges from 250 to $425 \mathrm{~mm}$ in Bütgenbach and from 240 to $458 \mathrm{~mm}$ in Robertville. Concerning $C$. peled there is globally one cohort in both lakes ranging from 350 to 530 $\mathrm{mm}$. Until 1995, there were few individuals with a size below $350 \mathrm{~mm}$. After restocking with $C$. peled has been stopped in 1996 these size classes were not captured anymore. Some larger individuals with a size over $540 \mathrm{~mm}$ have been captured only until 1996. 


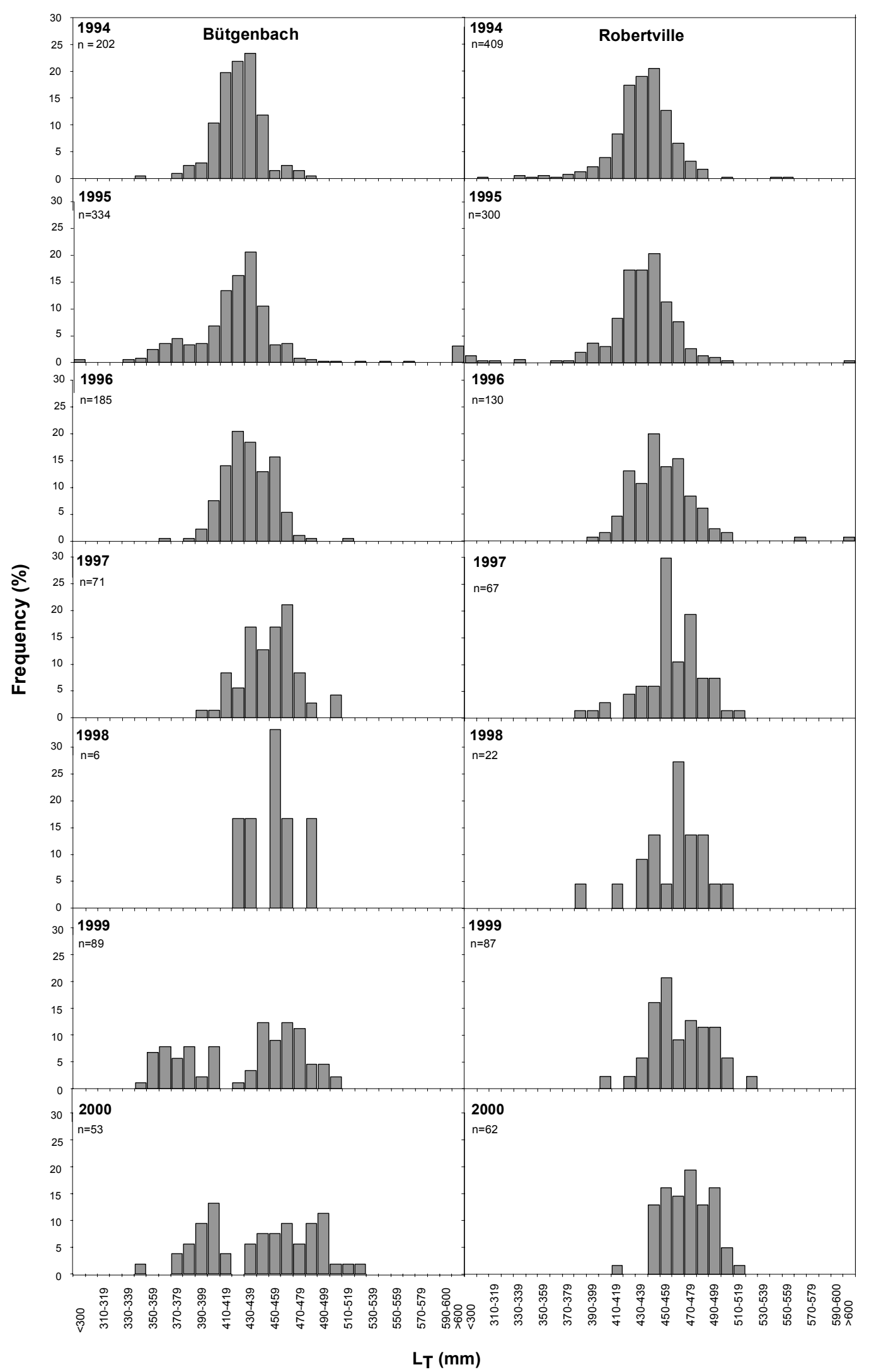

Figure 3. Length frequency distributions of C. peled in Bütgenbach (left column) and Robertville (right column) reservoirs from 1994 to 2000. 
Length-weight relationships for $C$. peled have been compared for the two reservoirs (Fig. 4).
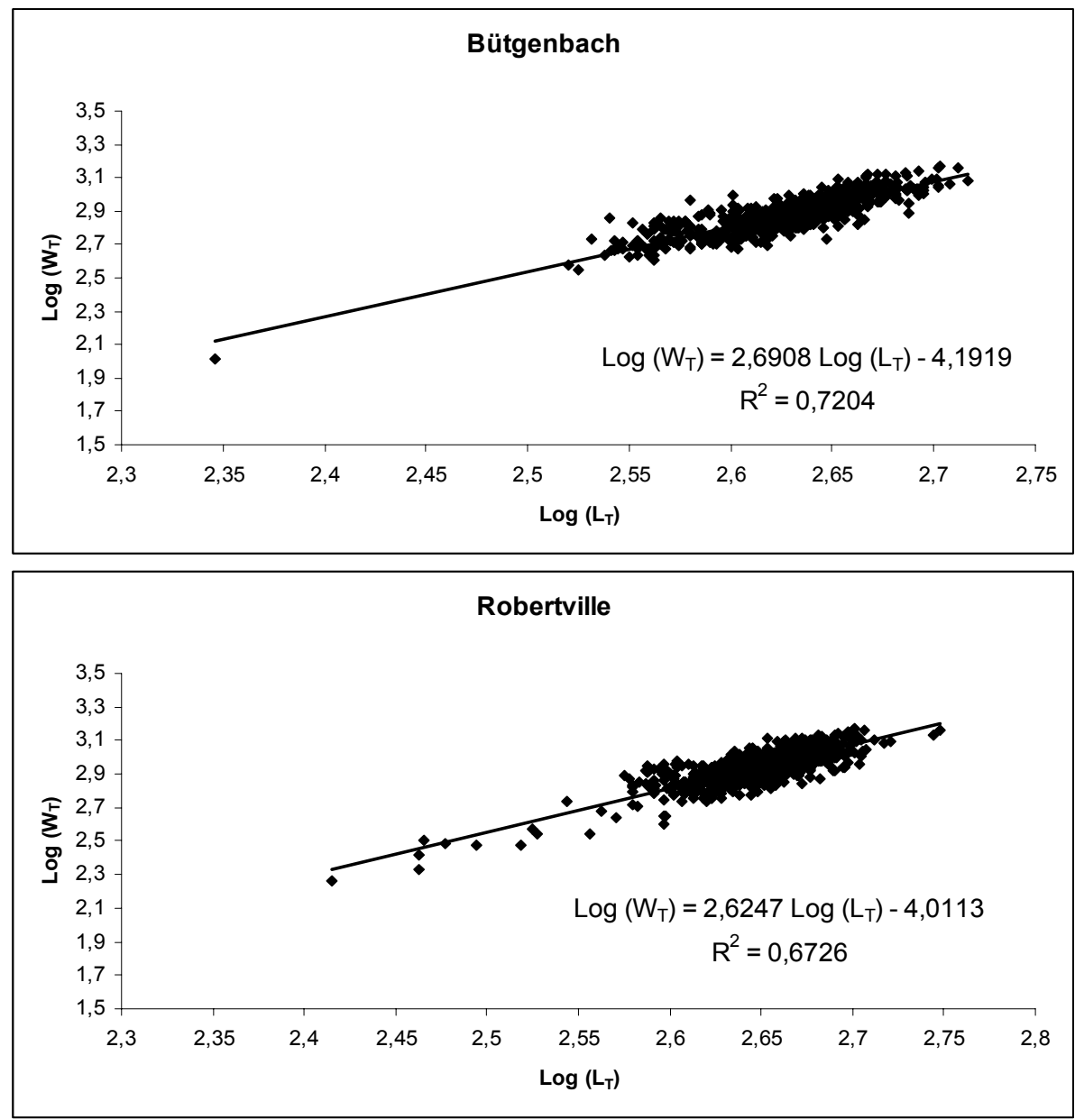

Figure 4. Logarithmic Length- Weight relationship for C. peled in the Bütgenbach (A) and Robertville $(B)$ reservoirs ( $L_{T}=$ total length in $\mathrm{mm}, W_{T}=$ total weight in $\mathrm{g}$ )

After linear logarithmic tranformation, the following relationships (Eq.1) are obtained for Bütgenbach:

$$
\log W_{t}=2.69 * \log L_{t}-4.19, \mathrm{r}^{2}=0.72
$$

and for Robertville:

$$
\log W_{t}=2.62 * \log L_{t}-4.01, \mathrm{r}^{2}=0.67 .
$$

The slopes of these two equations do not differ significantly (modified t-Student homogeneity of slope tests, $\mathrm{t}=0.8$, d.f. $=1805, \mathrm{p}=0.85$ ). Mean allometric growth condition factors equal 0.94 for Bütgenbach and 1.09 for Robertville. Both factors do not differ significantly (Student's $t$ test: $\mathrm{t}=-1.34, \mathrm{n}=1809, \mathrm{p}=0.18$ ).

Von Bertalanffy's growth models (Eq.2) were estimated for the 1996 captures [26]. In Robertville the model equation for $C$. peled is

and for C. lavaretus

$$
L_{t}=569 *\left[1-e^{-0.39 *(t+0.36)}\right]
$$

$$
L_{t}=508 *\left[1-e^{-0.25 *(t-0.20)}\right]
$$


In Bütgenbach the model equation for C. peled is

$$
L_{t}=796 *\left[1-e^{0.19^{*}(t-0.30)}\right]
$$

The abundance of C. lavaretus was too low in Bütgenbach to use the growth model.

\section{Diet Analysis}

Diet analyses were conducted on the fish captured in 1996 and 1997 by [7] in Robertville reservoir. C. lavaretus has a broad diet spectrum with 14 categories (Fig. 5 $A, B, C)$. There were benthic organisms (chironomids, gammaridae and molluscs) as well as zooplankton (Daphnia and cyclopoid copepods) or surface insects. Gravel and plant debris were frequently found in stomachs. Microcystis colonies were found in all stomachs in November and March but with an abundance index below $10 \%$. Chironomid larvae are the dominant prey items in terms of abundance during the three periods. Cyclopoid copepods are important prey items in November, while Gammaridae are important in November and December. In December and March, pollen is well represented in term of abundance. $C$. peled eggs are found in the stomachs of $C$. lavaretus in December. $C$. peled has a narrower diet spectrum with only 6 categories (Fig. $5 \mathrm{D}, E, F$ ). Zooplankton constitutes the main prey category during the three periods. Cyclopoid copepods have an abundance index higher than $80 \%$. Daphnia are less consumed, especially in March. Microcystis colonies have an occurrence between 10 and $20 \%$ in November and December and of more than $80 \%$ in March.

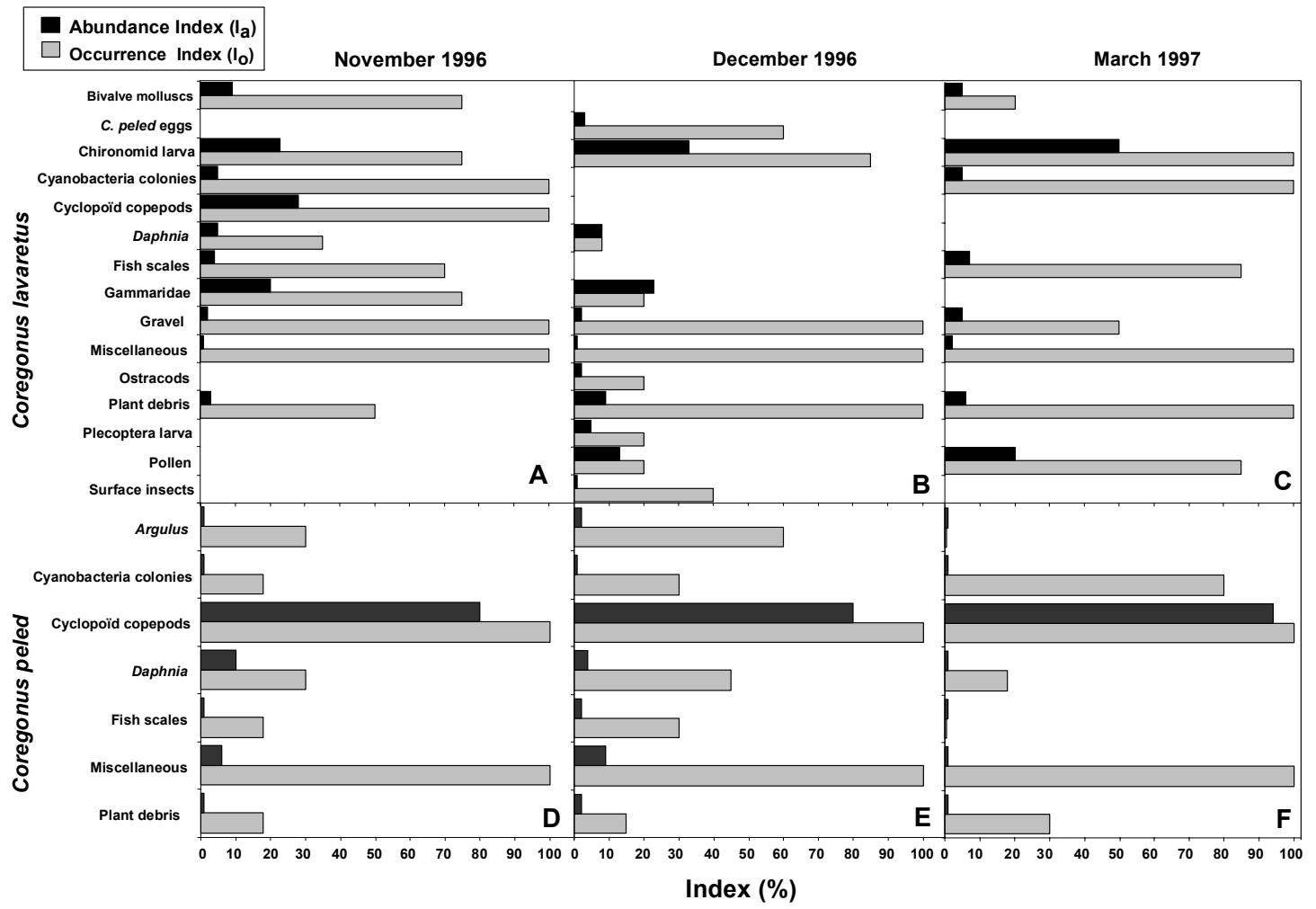

Figure 5. Occurrence (Eq.3) and Abundance(Eq.4) Indexes (\%) for C. lavaretus (A, B, $C$ ) and C. peled (D, E, F) in the Robertville Reservoir in 1996 and 1997 [7]. 
The diet analyses in 1999 and 2000 [23, 40] only concern $C$. peled in both lakes, as no $C$. lavaretus has been captured during this period. In the summer of 1999 in Bütgenbach, the main food items of $C$. peled were Bosmina, Daphnia, the cyclopoid and calanoid copepods, cladoceran and copepod eggs (Fig. 6 A). For each of these categories the Occurrence Index was higher than $90 \%$. Other food categories such as nauplii, Argulus coregoni, Hydracarina and Ceriodaphnia were only occasionally present with Occurrence Indexes below $10 \%$. In terms of abundance, the bestrepresented prey item was Bosmina coregoni (O.F. Müller 1785) for the same period $\left(\mathrm{I}_{\mathrm{a}}=37 \%\right)$. Copepod eggs have an $\mathrm{I}_{\mathrm{a}}$ of approximately $30 \%$ followed by Daphnia and cyclopoid copepods with an $\mathrm{I}_{\mathrm{a}}$ of more or less $15 \%$ each. Considering only the main zooplankton preys, Bosmina represents more or less $58 \%$ of the ingested biomass (Fig. 7 A). Daphnia represents approximately $22 \%$, and the cyclopoid copepods $10 \%$ in terms of biomass. As shown by the selectivity indexes (Fig. $8 \mathrm{~A}$ ) the preferred preys for this period in Bütgenbach are Bosmina coregoni and Daphnia. During the summer of 1999 in Robertville the main and the secondary prey items were the same as in Bütgenbach (Fig. 6 D), but their abundances differed. Cyclopoid copepods are dominant $\left(\mathrm{I}_{\mathrm{a}}=45 \%\right)$, followed by copepod eggs $\left(\mathrm{I}_{\mathrm{a}}=35 \%\right)$ and Bosmina $\left(\mathrm{I}_{\mathrm{a}}=15 \%\right)$. Among zooplankton preys (Fig. 7 B) cyclopoid copepods are dominant in biomass $\left(\mathrm{I}_{\mathrm{b}}>\right.$ $60 \%$ ), followed by Bosmina $\left(\mathrm{I}_{\mathrm{b}}=33 \%\right)$. Bosmina is largely selected in this lake (Fig. 8 $B)$.

In the autumn of 1999 in Bütgenbach, the main food items were Daphnia, Bosmina, Microcystis colonies, calanoid and cyclopoid copepods, Diaphanosoma, cladoceran and copepod eggs, and Volvox (Fig. 6 B). Each of these categories had an Occurrence Index higher than $70 \%$. The other categories are only occasionally present. The zooplankton preys are the most abundant, with Bosmina coregoni representing more or less $65 \%$. Daphnia is predominant in biomass $\left(\mathrm{I}_{\mathrm{b}}=50 \%\right)$, followed by Microcystis colonies $\left(\mathrm{I}_{\mathrm{b}}=\right.$ $18 \%)$, Diaphanosoma $\left(\mathrm{I}_{\mathrm{b}}=12 \%\right)$ and cyclopoid copepods $\left(\mathrm{I}_{\mathrm{b}}=8 \%\right)($ Fig. 7 A). The preferred prey items are respectively Ceriodaphnia, Bosmina and Diaphanosoma (Fig. $8 \mathrm{~A}$ ).

In the autumn of 1999 the main food items in Robertville are again the same as in Bütgenbach (Fig. 6 E), but the secondary prey items are less diversified. Bosmina is the only well represented category $\left(I_{a}>55 \%\right)$. The other categories have an $I_{a}$ below $12 \%$ such as Microcystis colonies and Diaphanosoma. Microcystis colonies and Volvox represent the bulk of biomass, with an $\mathrm{I}_{\mathrm{b}}$ of $83 \%$ and respectively $12 \%$ (Fig. $7 \mathrm{~B}$ ). The preferred prey items are Diaphanosoma and Bosmina (Fig. 8 B).

In the spring 2000 for the Bütgenbach Reservoir the main prey categories are Bosmina, cyclopoid copepods and cladoceran and copepod eggs with an $\mathrm{I}_{0}$ higher than $95 \%$ (Fig. 6 C). Daphnia has an occurrence of $55 \%$. The secondary prey items are Keratella cochlearis, Hydracarina and Ceriodaphia, Microcystis colonies and fish scales $\left(\mathrm{I}_{\mathrm{o}}\right.$ between $6 \%$ and $\left.12 \%\right)$. Bosmina coregoni is the most abundant prey item with an $I_{a}$ of $51 \%$, followed by cyclopoid copepods $\left(I_{a}=20 \%\right)$ and copepod eggs $\left(I_{a}=\right.$ $15 \%$ ). Bosmina coregoni dominates biomass with an $\mathrm{I}_{\mathrm{b}}$ of $70 \%$, followed by cyclopoid copepods $\left(\mathrm{I}_{\mathrm{b}}=12 \%\right)$ and Daphnia $\left(\mathrm{I}_{\mathrm{b}}=8 \%\right)$ (Fig. $\left.7 \mathrm{~A}\right)$. In early spring the preferred prey item are cyclopoid copepods, while in late spring the preferred items are Bosmina and calanoid copepods (Fig. $8 \mathrm{~A}$ ).

In the spring of 2000 in the Robertville Reservoir, the main prey categories are the same as in Bütgenbach for the same period. Microcystis colonies are more frequent than in Bütgenbach with an $\mathrm{I}_{0}$ of $22 \%$ (Fig. 6 F). Except for Keratella cochlearis and 
Ceriodaphnia, the secondary categories are similar as in Bütgenbach. Copepod eggs are the most abundant $\left(\mathrm{I}_{\mathrm{a}}=56 \%\right)$ followed by the cyclopoid copepods and Bosmina with an $\mathrm{I}_{\mathrm{a}}$ of more or less $15 \%$ each. Bosmina has a Biomass Index higher than $50 \%$, followed by cyclopoid copepods $\left(\mathrm{I}_{\mathrm{b}}=26 \%\right)$ and Daphnia $\left(\mathrm{I}_{\mathrm{b}}=12 \%\right)($ Fig. 7 B). In early spring the preferred prey items are Daphnia and cyclopoid copepods, while in late spring the only preferred items are cyclopoid copepods (Fig. 8 B).

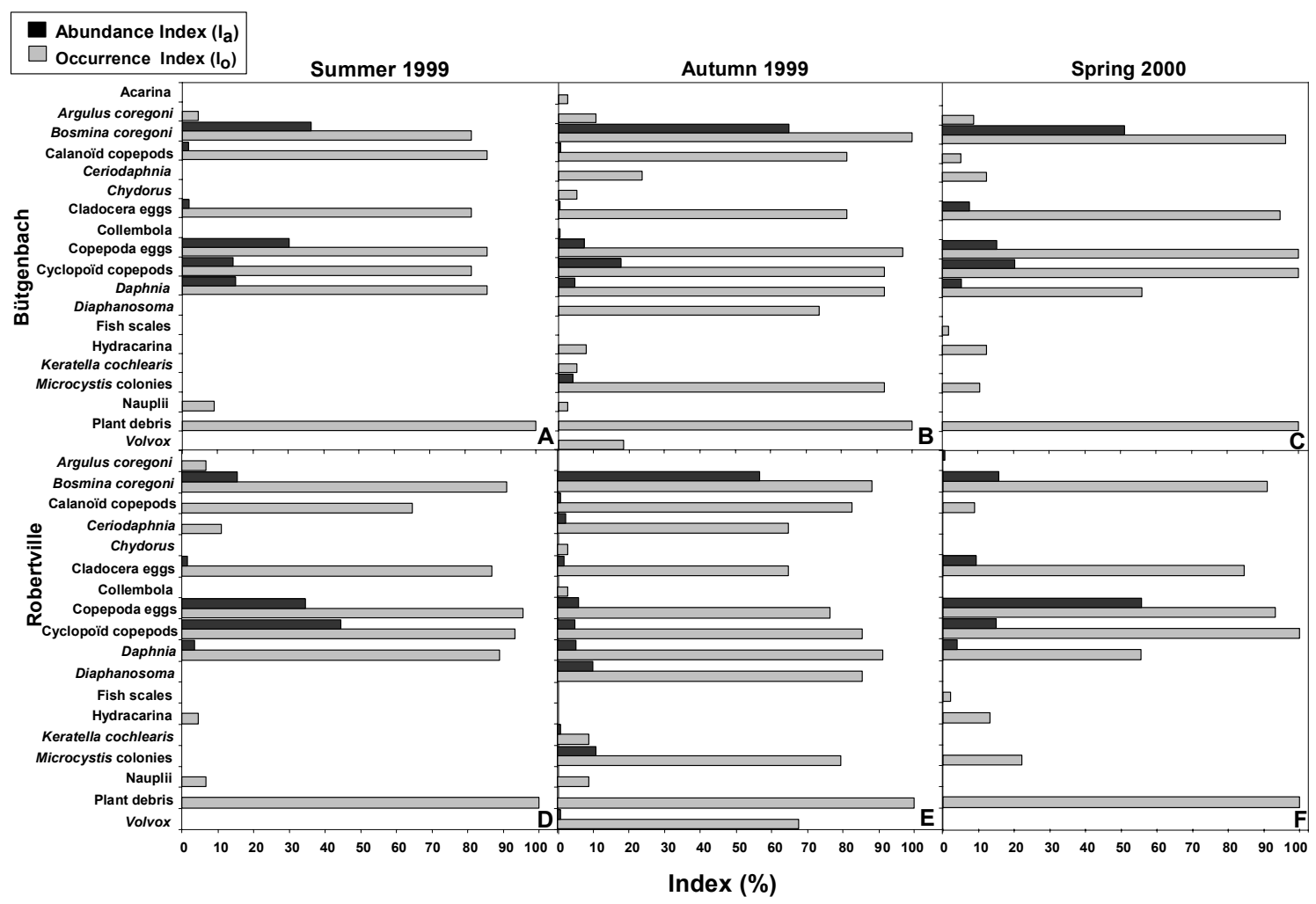

Figure 6. Occurrence(Eq.3) and Abundance (Eq.4) Indexes (\%) for C. peled in the Bütgenbach $(A, B, C)$ and Robertville (D, E, F) Reservoirs in 1999 and 2000 [22, 39]

\section{Discussion}

Fish habitat in lakes is strongly constrained by water temperature and available dissolved oxygen [11]. Coregonids need oligothrophic to mesotrophic waters, cool and well oxygenated. Lethal temperature for C. lavaretus is more or less $22^{\circ} \mathrm{C}$ with an optimum of less than $15^{\circ} \mathrm{C}$ [8]. According to [30] C. peled is more tolerant dealing with temperatures ranging from 0 to $28^{\circ} \mathrm{C}$, but on the other hand [44] recommends water temperatures below $25^{\circ} \mathrm{C}$. During our investigation periods the temperatures were relatively cool in both lakes except during the summer where surface water temperatures are likely to rise above $20^{\circ} \mathrm{C}$. These values are acceptable for $C$. peled but slightly too high for an optimal development of $C$. lavaretus. Threshold values for dissolved oxygen are $4 \mathrm{mg} / \mathrm{l}$ and oxygen saturation in hatching areas must be above 70 $\%$ [8] for both species. During thermal stratification periods the hypolimnion is anoxic in both lakes as well in 1996 as in 1999/2000. Threshold values are already reached at 7 $\mathrm{m}$ depth in Bütgenbach and around $10 \mathrm{~m}$ in Robertville. 


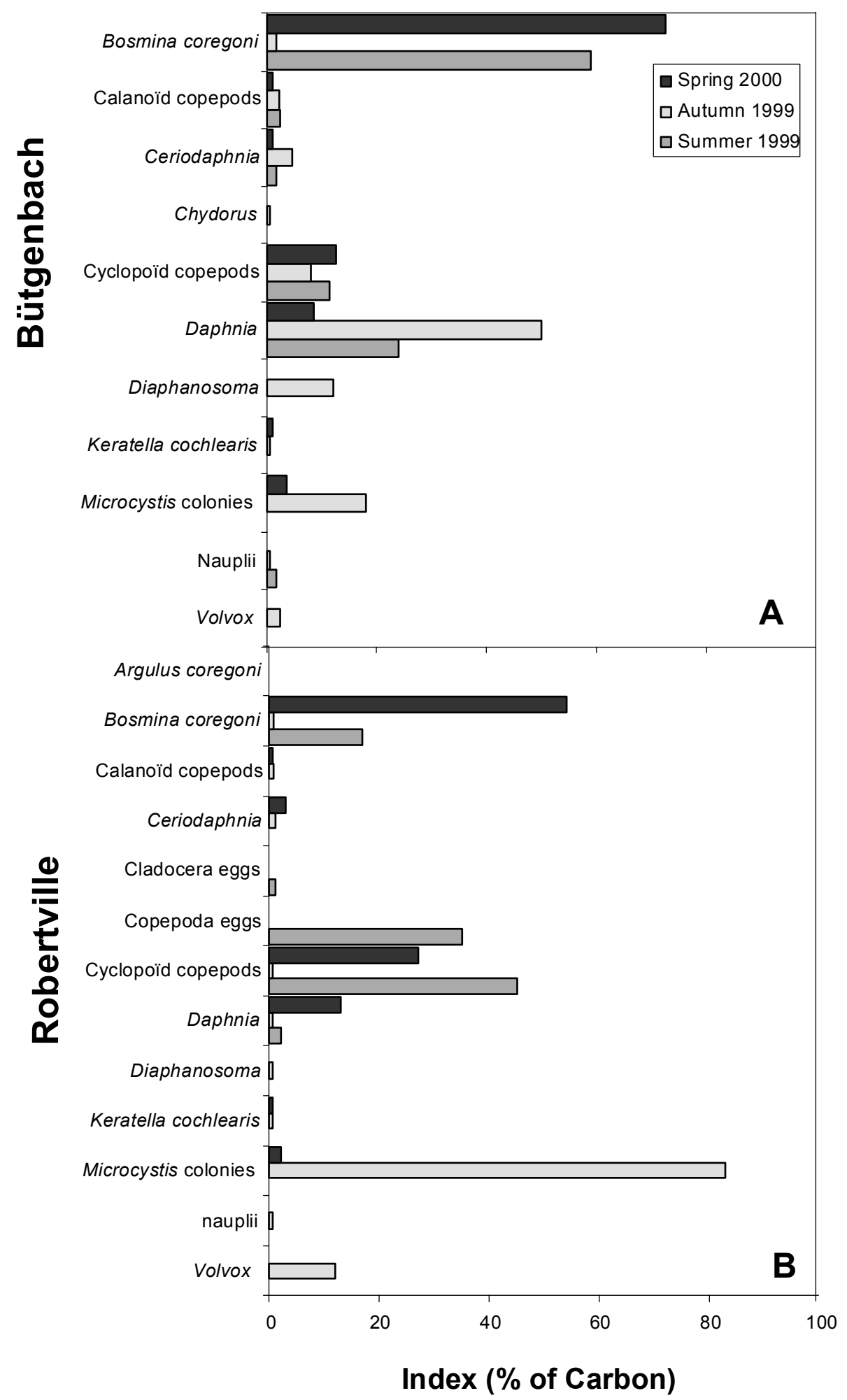

Figure 7. Biomass (Eq.5) Index (\% of Carbon) calculated for main categories of prey items in the diet of $\mathrm{C}$. peled in the Bütgenbach (A) and Robertville (B) Reservoirs in 1999 and 2000 [22, 39]. 


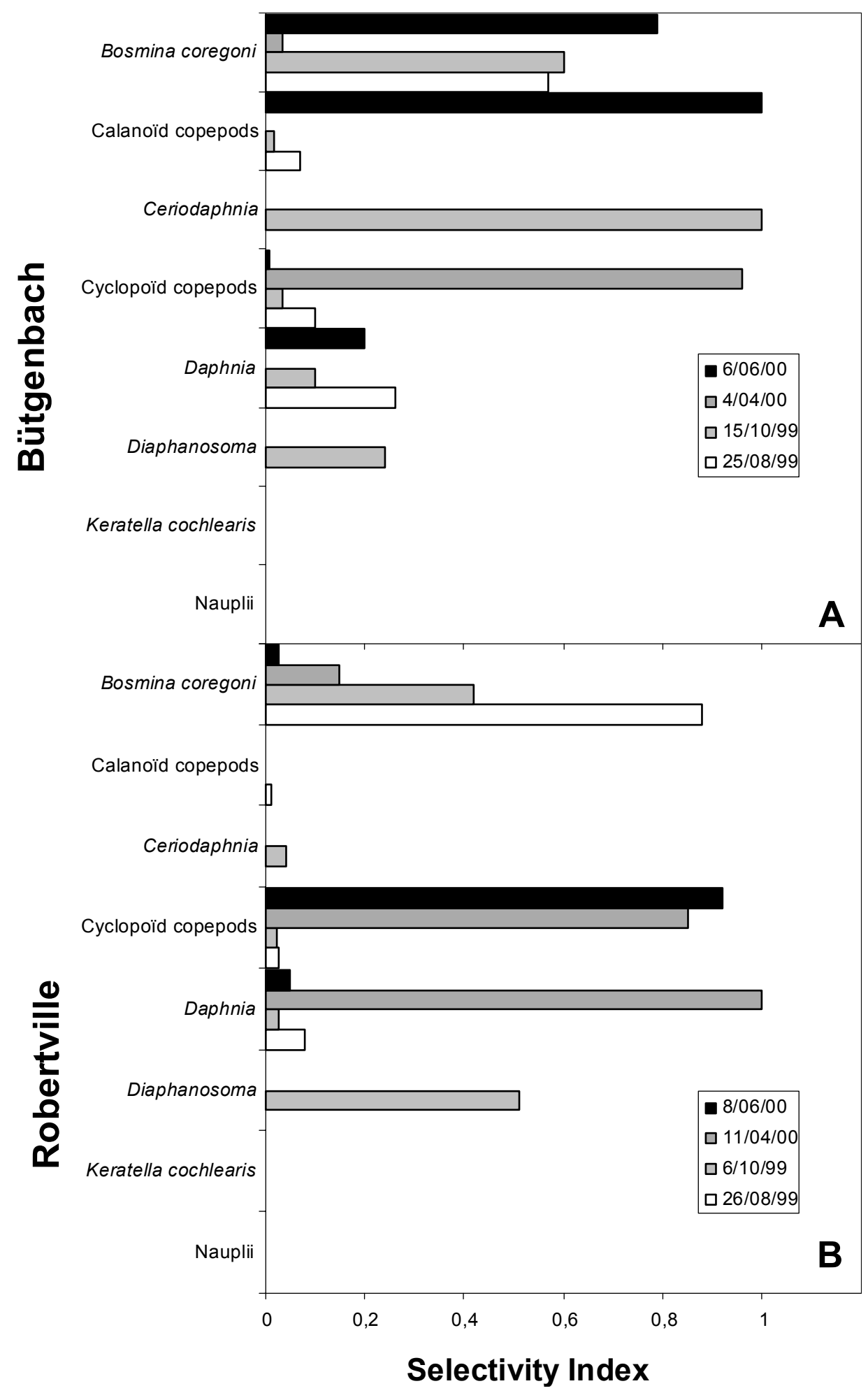

Figure 8. Chesson's Selectivity (Eq.6) Index calculated for main categories of zooplanktonic prey items in the diet of $\mathrm{C}$. peled in the Bütgenbach (A) and Robertville (B) Reservoirs in 1999 and 2000 [22, 39] 
In order to remain in their acceptable range for dissolved oxygen, the coregonids must stay in surface water during stratification, although water temperature is largely above their optimum in these water layers. Our results also show that the Robertville reservoir is less eutrophicated than the Bütgenbach reservoir according to their Chlorophylle $a$ values.

Length frequency diagrams established for $C$. peled in both lakes show only older cohorts, which indicates that there is no natural reproduction. Indeed [47 in 13] showed for the Mazurian Lakes that eutrophication, predation and bad weather conditions are responsible for losses higher than $95 \%$ during embryonic phase of vendace $(C$. albula L.) and $C$. lavaretus. In the most eutrophicated lakes there is no hatching and the coregonids populations have to be maintained by restocking.

Slope coefficients for $C$. peled in both lakes indicate an allometric growth $(b<3)$, length increasing proportionally more rapidly than weight. For $C$. peled in the Robertville Reservoir $\mathrm{L}_{\infty}$ equals $56.9 \mathrm{~cm}$, while in the Bütgenbach reservoir $\mathrm{L}_{\infty}$ equals $79.6 \mathrm{~cm}$. These values are a bit higher than those reported in Siberian $(51.8 \mathrm{~cm})$, Polish $(42.7 \mathrm{~cm})$ and Mongolian $(45.1 \mathrm{~cm})$ lakes by [44], but still within the range of the maximum length cited by [30]. Infinite length of $C$. lavaretus is $50.8 \mathrm{~cm}$ in the Robertville Reservoir. Values reported in the literature vary between 36.8 and $94.7 \mathrm{~cm}$ $[45,35]$.

For C. lavaretus, the results from 1996/1997 in Robertville show a broad diet spectrum with 14 categories. This is in agreement with the findings of several authors $[13,41,20,3,6]$. On the other hand $C$. lavaretus was also reported as exclusively zooplanktivorous [29, 43, 44, 2]. Some authors describe a diet composed of zooplankton and adult and larval insects [36, 28, 31, 32]. According to these results adults of $C$. lavaretus can adapt their diet as exclusively zooplanktivorous, benthic or mixed in relation to the prey availability in their habitat. Consumption of fish eggs by Coregonids and especially $C$. lavaretus is frequently cited [41, 31, 18]. [37] and [31] considered cannibalism on their own eggs as a common trait of $C$. lavaretus, such as in Loch Lomond where coregonid eggs constitute the major food item in the stomach contents of the fishes captured in January.

C. peled seems to have a more narrow diet spectrum. General diet characteristics are similar in both lakes, but a seasonal variation in main prey categories could be noticed. In winter in Robertville main prey are cyclopoid copepods. In spring and summer copepods and cladocerans are more balanced. In autumn, cladocerans become dominant with Bosmina coregoni. We have no data for the winter period in Bütgenbach, but for the three other periods the tendencies are the same, except for the relative contribution of Bosmina, who is higher especially in spring and summer. C. peled is an omnivorous species, which can adapt largely to the food availability $[44,39]$. In our case $C$. peled shows an essentially zooplankton oriented diet in both lakes with cladoceran and copepod species being the same as those frequently reported [22, 15, 24].

Cyanobacterial colonies are found in stomach contents in both species for both lakes, essentially in autumn, but their abundance does generally not exceed $10 \%$. The presence of cyanobacteria was reported by only a few authors [4, 44].

In conclusion, the Bütgenbach and Robertville reservoir lakes seem to meet the habitat requirements of $C$. lavaretus and $C$. peled in terms of growth capacities and diet composition. On the other hand, the conditions necessary for the natural reproduction of these two species do not seem to be totally fulfilled, probably due to the trophic status of the reservoirs and the fluctuations of the water level as consequence of reservoir 
operations. Meanwhile coregonid populations are sustained by restocking. In situ cagerearing of $C$. lavaretus juveniles to enhance restocking procedures is presently tested in the Robertville reservoir.

Acknowledgements. We wish to thank the "Ligue Royale de Propagande des Pêcheurs de l'Est", the " Services extérieurs de la pêche" and the "Centre de Recherche de la Nature, des Forêts et du Bois" of the Wallon Region for their support. A special thanks to all volunteers, who participated in the fishing campaigns.

\section{REFERENCES}

[1] Amoros, C. (1984): Crustacés Cladocères, Introduction à la Systématique des Organismes des Eaux Continentales Françaises. - Bulletin mensuel de la Société Linnéenne Lyon 53.

[2] Becker, M. \& Eckmann, R. (1992): Plankton selection by pelagic european whitefish in Lake Constance: dependency on season and time of day. - Polskie Archiwum Hydrobiologii 39, 393-402.

[3] Berg, S., Jeppesen, E., Sondergraard, M. \& Mortensen, E. (1994): Environmental effects of introducing whitefish, Coregonus lavaretus (L.), in Lake Ring. - Hydrobiologia 275/276, 71-79.

[4] Bergstrand, E. (1982): The diet of four sympatric whitefish species in Lake Parkijaure. Report of the Institute of Freshwater Research Drottningholm 60, 5-14.

[5] Bertalanffy, L. von (1938): A quantitative theory of organic growth (Inquiries on growth laws. II). - Human Biology 10, 181-213.

[6] Bøhn, T. \& Amundsen, P.-A. (1998): Effects of invading vandace (Coregonus albula L.) on species composition and body size in two zooplankton communities of the Pasvik River System, nothern Norway. - Journal of Plankton Research 20, 243-256.

[7] Bouda, S. (1997): Contribution à l'étude des populations de Coregonus lavaretus (Linneus, 1758) et de Coregonus peled (Gmelin, 1788) des lacs de barrage de Bütgenbach et de Robertville en Haute Belgique. - Mémoire présenté pour l'obtention du Diplôme d'Etude Complémentaires en Eco-technologie des Eaux Continentales, Facultés Universitaires Notre-Dame de la Paix, Namur.

[8] CECPI (1996): Directives pour le repeuplement en corégones. - Document CECPI 31. Rome: FAO.

[9] Chesson, P. L. 1978. Predator-prey theory and variability. - Annual Review of Ecology and Systematics 9:323-347.

[10] Dagnélie, P. (1970): Théorie et Méthodes statistiques, Tome II. - Gembloux: Les Presses Agronomiques de Gembloux.

[11] Fang, X.; Stefan, H. G.\& Alam, S. R. (1999): Simulation and validation of fish thermal DO habitat in North-Central US lakes under different climate scenarios. - Ecological Modelling 188, 167-191.

[12] FAO (1997): FAO Database on Introduced Aquatic Species. - Rome: FAO.

[13] Gasowska, M. (1953): The withefish of the Mazurian lakes. - Roczn. Nauk Roln. 67 B-1, 81-100.

[14] Gillet, C. (1989): Le déroulement de la fraie des principaux poissons lacustres. Hydroécologie Appliquée 1/2, 117-143.

[15] Hakkari, L., Westman, K., Selin, P. \& Mielonen, M. (1984): The food of the native whitefish (Coregonus muksun (Pallas)) and the introduced whitefish (C. peled (Gmelin)) stocked in the same small forest lakes in southern Finland. - EIFAC Technical Paper 42, 109-122.

[16] Harding, J.P. \& Smith, W.A. (1974): Cyclopoïds and calanoïds copepods, a key to the British Freshwater. - Scientific Publication of the Freschwater Biological Association, 18. 
[17] Holcík, J. (1991): Fish introductions in Europe with particular reference to its central and eastern part. - Canadian Journal of Fisheries and Aquatic Sciences 48,13-23.

[18] Hudd, R., Leskelä, A., Wiik, T. \& Lehtonen, H. (1992): Food of european whitefish (Coregonus lavaretus widegreni) larvae and fry in southern Bothnian Bay (Baltic). Polskie Archiwum Hydrobiologii 39, 473-478.

[19] Hyslop, E.J. (1980): Stomach content analysis a review of methods and their application. - Journal of Fish Biology 17, 411-429.

[20] Jacobsen, O. J. (1982): A review of food and feeding habits in coregonid fishes. - Polskie Archiwum Hydrobiologii 29, 179-200.

[21] Le Cren, E. D. (1951): The length-weigth relationship and seasonal cycle in gonad weight and condition in the perch (Perca fluviatilis). - Journal of Animal Ecology 20, 201-219.

[22] Lindström, T. (1962): Life history of whitefish young (Coregonus) in two lake reservoirs. - Report of the Institute of Freshwater Research Drottningholm 44, 113-144.

[23] Malbrouck, C. (2000): Etude de différentes espèces de corégones et de leur régime alimentaire en vue de leur valorisation halieutique dans les lacs de barrage de Bütgenbach et de Robertville, Rapport final : période juillet 1999. juin 2000. - Namur: Ministère de la Région Wallonne, DGRNE.

[24] Mamcarz, A. \& Murawska, E. (1988): Studies on the larvae and fry feeding of the two Coregonidae species during its first year of growth in illuminated cages. - Acta Ichtyol. Piscat. 18, 51-71.

[25] Mergen, P. (2002): Distribution spatio-temporelle des communautés ichtyologiques dans les lacs de barrage de Nisramont (Belgique) et d'Esch-sur-Sûre (Grand-Duché du Luxembourg). - Dissertation Doctorale, Facultés Universitaires Notre-Dame de la Paix. Namur: Presses Universitaires de Namur.

[26] Mergen, P., Kestemont, P. \& Micha, J.-C. (1996): Convention relative à l'étude des populations piscicoles dans les lacs de barrage. - Ministère de la Région Wallonne, DGRNE.

[27] Muus, B.J. \& Nielsen, J.G. (1999): Sea fish. - Scandinavian Fishing Year Book. Hedehusene, Denmark.

[28] Naesje, T. F., Jonsson, B. \& Sandlund, O. T. (1991): Habitat Switch and Niche Overlap in Coregonid Fishes: Effects of Zooplankton Abundance. - Canadian Journal of Fisheries and Aquatic Sciences 48, 2307-2315.

[29] Nilsson, N.-A. (1965): Food segregation between salmonid species in North Sweden. Report of the Institute of Freshwater Research Drottningholm 46, 95-123.

[30] Pivnicka, K., Cerny, K. \& Hisek, K. (1987): Poissons. - Paris: Gründ.

[31] Pomeroy, P.P. (1991): A comparative assessment of temporal variation in diet of powan, Coregonus lavaretus (L.), Loch Lomond and Loch Eck, Scotland, U.K. - Journal of Fish Biology 38, 457-478.

[32] Pomeroy, P.P. (1994): Zooplankton in Loch Lomond: perspectives, predation and powan. - Hydrobiologia 290, 75-90.

[33] Pontin, R. M. (1978): A key to British Freshwater Planktonic Rotifera. - Scientific Publication of the Freschwater Biological Association, 38.

[34] Ricker, W. (1971): Methods for assessments of fish production in freshwater. - Oxford: Blackwell Science Publications.

[35] Salojärvi, K. (1991): Compensation in a Whitefish (Coregonus lavaretus L. s.1.) population maintained by stocking in lake Kallionen, Northern Finland. - Finnish Fisheries Research 12, 65-76.

[36] Sandlund, O. T., Naesje, T. F. \& Kjellberg, G. (1987): The size selection of Bosmina longispina and Daphnia galatea by co-occurring Cisco (Coregonus albula), whitefish $(C$. lavaretus) and smelt (Osmerus eperlanus). - Archiv für Hydrobiologie 110, 357-363.

[37] Skurdal, J., Bleken, E. \& Stenseth, N.C. (1985): Cannibalism in whitefish (Coregonus lavaretus). - Oecologia 67, 566-571. 
[38] Smayda, T.J. (1978): From phytoplankters to biomass. - In: Phytoplankton manual. A. Sounia (ed.) UNESCO, Paris: 273-279.

[39] Szczerbowski, A. (1992): Characteristics of the spawning population of peled (Coregonus peled Gmel.) in Lakes Dluzek and Gasiorowo. - Polskie Archiwum Hydrobiologii 39, 853-862.

[40] Tigny, V. (2000): Contribution à l'étude du régime alimentaire des Coregonus peled des lacs de barrage de Robertville et Bütgenbach en vue de préciser leur position au sein du réseau trophique. - Mémoire présenté pour l'obtention du grade d'Ingénieur Agronome. Université Catholique de Louvain, Faculté des Sciences Agronomiques, Louvain-LaNeuve.

[41] Valtonen, E. T. (1980): Metechinorhynchus salmonis infection and diet in the riverspawning whitefish of the Bothnian Bay. - Journal of Fish Biology 17, 1-8.

[42] Viroux L. (2000): Dynamique du métazooplancton en milieu fluvial. - Dissertation Doctorale, Facultés Universitaires Notre-Dame de la Paix. Namur: Presses Universitaires de Namur.

[43] Vostradovska, M. (1966): First experiences with great maraena (Coregonus lavaretus maraena Bloch 1799) from the Jesenice River Basin. - Zivocisna Vyroba 11, 723-728.

[44] Vostradovsky, J. (1986): The future of coregonids in man-made lakes in Czechoslovakia. - Archiv für Hydrobiologie 22, 141-149.

[45] Vostradovsky, J., Krizek, J., Ruzicka, L. \& Vostradovska, M. (1988): The biology of the whitefish hybrid between Coregonus lavaretus maraena Bloch and Coregonus peled Gmelin in man-made lakes in Czechoslovakia. - Finnish Fisheries research 9, 183-189.

[46] Welcomme, R.L. (1988): International introductions of inland aquatic species. - FAO Fisheries Technical Paper 294.

[47] Wheeler, A.. (1992): A list of the common and scientific names of fishes of the British Isles. - Journal of Fish Biology 41, 1-37.

[48] Wilkonska, H. \& Zuromska, H. (1982): Effect of environmental factors and egg quality on the mortality of spawn in Coregonus albula (L.) and Coregonus lavaretus (L.). Polskie Archiwum Hydrobiologii 29, 123-158. 